Jan 2021. American Journal of Public Health.

\title{
WAge-Setting Policies, EMPlOYMENT, AND FOOD INSECURITY: A MULTILEVEL ANALYSIS OF 492,078 PEOPLE IN 139 COUNTRIES
}

\section{Aaron Reeves ${ }^{*}$, Rachel Loopstra ${ }^{\dagger}$ and Valerie Tarasuk ${ }^{\ddagger}$}

May 11, 2021

\begin{abstract}
:
Background: Wage-setting policies, which increase earnings, may reduce the risk of food security, but the impact of these policies may vary depending on employment status.

Method: We estimated multilevel regression models, using data from the Gallup World Poll (2014-2017) and UCLA's World Policy Analysis Center, to examine the association between wage setting policy and food insecurity across 139 countries $(n=492,078)$.
\end{abstract}

Results: Compared to countries with little or no minimum wage, the probability of being food insecure was 0.10 lower $(95 \% \mathrm{CI}$ : $0.02,0.18)$ in countries with collective bargaining. However, these associations varied across employment status. More generous wage setting policies (e.g., collective bargaining or high minimum wages) were associated with lower food insecurity among full-time workers (and to some extent part-time workers) but not those who are unemployed.

Conclusions: In countries with generous wage setting policies, employed adults had a lower risk of food insecurity but the risk of food insecurity for the unemployed was unchanged. Wage setting policies may be an important intervention for addressing risks of food insecurity among

\footnotetext{
${ }^{*}$ Department of Social Policy and Intervention, University of Oxford, aaron . reeves@spi . ox . ac . uk ${ }^{\dagger}$ Department of Nutritional Sciences, King's College London

${ }^{\ddagger}$ Department of Nutritional Sciences, University of Toronto
} 


\section{INTRODUCTION}

Food insecurity - 'the uncertainty and insufficiency of food availability and access that are limited by resource constraints, and the worry or anxiety and hunger that may result from it $^{\prime 1}$ - is a global problem, affecting the health of millions. Food insecure adults have higher risk of depression, diabetes, and cardiovascular disease ${ }^{2,3}$ while children that have grown up in food insecure homes have poorer health and education outcomes. ${ }^{4,5}$ Food insecurity can even lead to stunting and wasting, ${ }^{6}$ both of which increase the risk of mortality. ${ }^{7}$ While the last 100 years brought significant reductions in chronic food deprivation, ${ }^{8}$ improvements in these trends have now stalled, ${ }^{9}$ with Covid-19 threatening to increase food insecurity globally. In this context, developing policies to address food insecurity is a key priority because 'ensur[ing] healthy lives and promot[ing] well-being for all' (United Nation's Sustainable Development Goal 3) is not possible without achieving food security. ${ }^{10}$

Food insecurity is largely rooted in socio-economic inequalities which undermine access to food. ${ }^{11}$ A recent global analysis of 134 countries illuminated this point: food insecurity was more likely in households with low incomes and where one household member was unemployed. ${ }^{12}$ This finding has been replicated in country-specific studies in high-income countries. ${ }^{13,14} \mathrm{Im}$ portantly, however, food insecurity has also been observed among the employed. Indeed, in a global dataset, over $50 \%$ of people who were food insecure were engaged in paid employment (authors' calculations using Food and Agriculture Organization (FAO) data). ${ }^{15}$ Workers in more precarious positions in the labour market (e.g., part-time employment) were also at heightened risk. ${ }^{16}$ Employment status, length of contract, and wages may all affect food insecurity risk. It follows, then, that policies which increase wages may influence the risk of food insecurity. ${ }^{17,18}$

Wage-setting policies often include rules that govern contract negotiations between employers and employees. Wage bargaining, for example, can occur (1) directly between an employer and an employee, (2) in the context of a minimum wage, which restricts the lowest amount someone can be paid for their labour, or (3) through collective bargaining arrangements, where wages are set by unions and firms together. ${ }^{19}$ Countries with collective bargaining or even high minimum wages may have lower food insecurity because these wage setting policies tend to increase earnings compared to countries that have less generous minimum wages or that do not regulate earnings at all. ${ }^{20}$ Collective bargaining arrangements could also reduce food insecurity through provision of non-income benefits, such as employer-paid health insurance, as healthcare costs increase the risk of food insecurity. ${ }^{21}$

Research into the impacts of wage-setting activities on food insecurity has been scarce. Some simulation studies suggest increasing the minimum wage would reduce food insecurity ${ }^{22}$ but there are significant gaps in our understanding of whether and how wage setting policies affect food insecurity. It is currently unclear, for example, whether the possible benefits of wage setting policies are concentrated among full-time workers. ${ }^{23}$ Part-time workers may not fully benefit because they work fewer hours and therefore benefit less from minimum wages. People who are unemployed or who are in informal employment may not benefit at all, as they are not directly impacted by wage setting policies. ${ }^{22}$ 
The net effect of wage setting policies on food insecurity may also depend on whether such policies create unemployment or lead to more part-time working, which in turn, may increase food insecurity. Whether minimum wages create unemployment remains a contested issue ${ }^{24}$ but it is possible that some people may lose their jobs and that some firms may increase the number of part-time workers to reduce costs. ${ }^{25}$ Thus, even if increasing the minimum wage improves earnings for some, others may lose out. This could mean food insecurity rises if the unemployed are not protected from experiencing food insecurity by other policies, such as unemployment insurance.

Lastly, when considering the impacts of wage setting policies, it is necessary to take into account the size of the informal economy, ${ }^{26}$ that is, the share of the population working outside the reach of labour market regulations. Higher minimum wages, for example, may reduce the risk of food insecurity, but these reductions could be diminished if labour market informality is high because more people are not regulated by these policies.

This paper makes a significant contribution to understanding of the relationship between wage setting policies and food insecurity by addressing two main questions. First, are wage setting policies correlated with risk of food insecurity (RQ1)? In particular, we tested the hypothesis that food insecurity will be lower in countries with collective bargaining and higher minimum wage policies compared to countries with little or no minimum wage policies. Then, second, do associations between wage setting policies and food insecurity differ between full-time employed, part-time employed, and unemployed (RQ2)? We also explored whether associations between wage setting policies and food insecurity were moderated by the size of the informal economy (RQ3).

\section{METHODS}

\section{DATA}

We used cross-sectional data from the Gallup World Poll (GWP) collected in each year from 2014 to 2017 in 147 countries. In these years, the GWP included the FAO's survey instrument for measuring food insecurity, the Food Insecurity Experience Scale (FIES), ${ }^{15}$ providing an experience-based measure of food insecurity. The GWP was conducted by telephone in countries where telephone coverage was at least $80 \%$ of the population and face-to-face questionnaires were used in contexts where this was not true. The survey aims to be nationally representative at the country level of the adult population (aged 15 and older). The FIES is used to produce a global measure of food insecurity as well as comparable country-level estimates of food insecurity around the world. ${ }^{12}$ The FIES comprises eight 'Yes/No' questions designed to elicit whether respondents faced difficulty or uncertainty in accessing sufficient food over the past 12 months. $15 \mathrm{We}$ summed responses across the 8 questions ( $1=$ Yes, $0=\mathrm{No}$ ) and converted the total score into three binary categories of food insecurity: ${ }^{27}$ any indication of food insecurity ( 1 or more 'Yes' responses), 'moderate/severe' food insecurity (4 or more 'Yes' responses), and 'severe only' food insecurity (7 or more 'Yes' responses). Each of these categories is examined separately because the influence of wage setting polices may differ in 
magnitude and strength of association across these indicators. 13

The GWP also contains a measure of employment status, which we recoded as: employed fulltime (reference $=0$ ), employed part-time (coded as 1 ), or not employed (coded as 2 ). The data set does contain a measure of self-employment, however, it is self-reported, so could vary in meaning across different contexts. Whether or not wage setting policies affect people in selfemployment may also differ by country context. These ambiguities introduce significant uncertainties in the analysis and interpretation of findings related to self-employment status, so, though we include self-employment as a category of employment in our regression models, we do not discuss it in the analysis. The GWP data set also provided data on respondent age, gender, marital status, social capital, social networks, and urban/rural location, which are all included in our models as covariates.

The GWP data was merged with country-level measures of wage setting policy taken from UCLA's World Policy Analysis Center, ${ }^{28}$ which produces a policy database constructed from the constitutional and legal provisions for workers in 193 countries. These data were collected in 2014, though policy change in this area is very stable and so very few countries would have changed between 2014 and 2017. For our analysis, we combined two variables contained in their database, the legislative context for wage-setting policies and the value of the minimum wage required by law, to create a new variable that had four non-overlapping categories. To increase comparability across countries, the minimum wage levels are expressed as Purchasing Power Parity Dollars (PPP\$), a currency conversion which adjusts for prices and therefore compares purchasing power. The four categories were defined as (1) Low ( $<$ PPP\$2 per day) or no minimum wage (19 countries; examples include Singapore and Bangladesh); (2) Moderate minimum wage set by law between PPP\$2 and PPP\$10 per day (58 countries; examples include Mexico and Ghana); (3) High minimum wage set by law above PPP\$10 per day (50 countries; examples include Morocco and the United States); and (4) Collective bargaining, where a minimum wage is not set by law but where wage negotiations are collectively organised (12 countries; examples included Bosnia Herzegovinia and Sweden).

Lastly, we merged these data with GDP per capita, adjusted for purchasing power and inflation, which we obtained from the World Bank. We also merged data on informal employment, also from the World Bank. These data provide an estimate of the proportion of the non-agricultural labour force engaged in informal employment (all jobs in unregistered or unincorporated enterprises). These data were not available for 67 countries (48\%) included in our merged GWPUCLA dataset. After merging these datasets and excluding cases with missing individual-level and country-level data, our final analytic sample comprised 492,078 individuals spanning up to 139 countries for the years 2014-2017 for our main analyses and 72 countries and 257,032 individuals for RQ3 (a full list of countries is included in web appendix 1).

\section{STATISTICAL ANALYSIS}

To evaluate the impact of wage-setting policy on food insecurity, we estimated separate multilevel, logistic regression models (with random intercepts) with standard errors clustered at the country-level to account for correlations between individuals living within the same country. 
The outcome variables across all models are the three measures of food insecurity described above. The main predictor variable is the measure of wage setting policy. The analysis proceeds in two steps. First, we estimated whether food insecurity was, on average, lower in countries that have implemented specific wage-setting policies (RQ1). Second, we tested for possible heterogeneity in the association between wage-setting policy and food insecurity according to employment status (RQ2). To do this, we estimated a cross-level interaction term between employment status and the type of wage-setting policy in place in that country. For each of these models, we estimated the predicted probability of being food insecure and then calculated the marginal effect of the policies (predicted at the means), that is the average difference in the predicted probability of being food insecure between countries that have different types of wage setting policies.

Models were adjusted for possible confounders. These included age because earnings are correlated with age and with food insecurity (an age-squared term was also added to account for any non-linearities). We also controlled for gender because women tend to face higher risk of food insecurity but may also be underrepresented in the labour market and therefore less affected by labour market policies. ${ }^{12}$ Marital status may also be a confounder because lone parents may face a higher risk of food insecurity and may also be less able to work. ${ }^{12}$ People in rural areas face an elevated risk of food insecurity but may also be less likely to work for an employer. ${ }^{12}$ Measures of social networks (respondent's satisfaction with their opportunities to make friends) and social capital (respondent's have people in their life they can count on) are included too because earlier work suggests these are correlated with both food insecurity and employment opportunities. ${ }^{12}$ Finally, our models control for GDP per capita because richer countries, on average, will have less food insecurity than poorer countries and GDP may also correlate with wage setting policies. ${ }^{17,18}$ More details on all variables are provided in web appendix 2 .

We also conducted an additional analysis which adds an interaction term between the proportion of people employed informally in the labour market and our measure of wage setting policy (RQ3). We did not include countries with collective bargaining in these models because none of these countries had data on labour market informality.

We also explored the robustness of our findings by conducting sensitivity tests, namely (1) excluding low-income countries (because very few low-income countries had high minimum wages or collective bargaining), retaining middle-income countries only, and then retaining high-income countries only; (2) controlling for other policies that might be correlated with food insecurity (such as family, pension, and maternity- and paternity-leave policies, as defined by the World Policy Analysis Center); and (3) conducting a matching analysis at the country level - matching on economic development, population size, the degree of democracy, and their geographical location (continent) - and thereby focusing on those parts of the distribution where there is common support. ${ }^{29}$ 


\section{RESULTS}

\section{ARE WAGE SETTING POLICIES ASSOCIATED WITH FOOD INSECURITY (RQ1)?}

More generous wage-setting policies were negatively associated with the predicted probability of food insecurity across all measures (any indication, moderate/severe, and severe), even after accounting for GDP and other control variables. In countries where there was no minimum wage or a low minimum wage, the probability of being moderately/severely food insecure was 0.31 (95\% CI: 0.25-0.36) (see Table 1). Moderate or severe food insecurity was only slightly lower in countries with moderate minimum wage policies $(0.29,95 \% \mathrm{CI}$ : $0.25-0.33)$. The probability of moderate or severe food insecurity was 0.25 (95\% CI: $0.21-0.30)$ in countries with high minimum wages. Lastly, the probability of food insecurity was lower still at 0.21 (95\% CI: 0.15-0.26) in countries with collective bargaining arrangements.

Table 1: Predicted probability of food insecurity by the type of wage setting policy and the difference in the predicted probability of food insecurity between countries with collective bargaining and other wage setting policies (Countries with Collective Bargaining as the reference)

\begin{tabular}{|c|c|c|c|}
\hline & $\begin{array}{l}\text { Any indication of } \\
\text { food insecurity }\end{array}$ & $\begin{array}{l}\text { Moderate or } \\
\text { severe food } \\
\text { insecurity }\end{array}$ & $\begin{array}{c}\text { Severe food } \\
\text { insecurity }\end{array}$ \\
\hline Wage setting policy & $(1)$ & $(2)$ & (3) \\
\hline Collective bargaining & 0.394 & 0.208 & 0.094 \\
\hline (Reference category) & {$[0.332,0.457]$} & {$[0.153,0.262]$} & {$[0.060,0.127]$} \\
\hline \multirow[t]{2}{*}{ High minimum wage } & 0.451 & 0.255 & 0.124 \\
\hline & {$[0.413,0.489]$} & {$[0.214,0.295]$} & {$[0.092,0.156]$} \\
\hline Difference between high & 0.057 & 0.047 & $0.030^{*}$ \\
\hline minimum wage and & {$[-0.002,0.116]$} & {$[-0.001,0.095]$} & {$[0.001,0.060]$} \\
\hline reference category & $p=0.059$ & $p=0.053$ & $p=0.049$ \\
\hline \multirow[t]{2}{*}{ Moderate minimum wage } & 0.489 & 0.293 & 0.154 \\
\hline & {$[0.444,0.533]$} & {$[0.252,0.334]$} & {$[0.126,0.182]$} \\
\hline Difference between moderate & $0.095^{*}$ & $0.085^{*}$ & $0.060^{*}$ \\
\hline minimum wage and & {$[0.006,0.183]$} & {$[0.009,0.162]$} & {$[0.012,0.109]$} \\
\hline reference category & $p=0.037$ & $p=0.029$ & $p=0.015$ \\
\hline \multirow[t]{2}{*}{ Little minimum wage } & 0.493 & 0.307 & 0.163 \\
\hline & {$[0.432,0.555]$} & {$[0.249,0.365]$} & {$[0.120,0.206]$} \\
\hline Difference between little & $0.099^{*}$ & $0.099^{*}$ & $0.070^{*}$ \\
\hline minimum wage and & {$[0.004,0.194]$} & {$[0.018,0.181]$} & {$[0.017,0.122]$} \\
\hline reference category & $p=0.049$ & $p=0.016$ & $p=0.010$ \\
\hline Countries & 139 & 139 & 139 \\
\hline Observations & 492,078 & 492,078 & 492,078 \\
\hline
\end{tabular}


Notes: Confidence intervals reported in parentheses. The estimated differences reported in the table are absolute differences in the predicted probability of food insecurity (predicted at the means), on average, between countries with collective bargaining and countries with other types of wage setting regime. Estimates come from a multilevel logistic regression model which controls for: sex, age, age-squared, marital status, whether respondents live in an urban or rural area, their employment status, whether there are children in the household under the age of 15 , whether respondents are satisfied with their opportunities to make friends, whether respondents have people in their life they can count on, and GDP per capita (adjusted for purchasing power and inflation, measured on a log scale). The categories of the wage setting policy measure are defined as follows: Little or no wage setting policy: Countries with either (a) no minimum wage or (b) a very low minimum wage ( $<$ PPP $\$ 2$ per day); Moderate minimum wage: Countries with a minimum wage set by law between PPP\$2 and PPP $\$ 10$ per day; High minimum wage: Countries with a minimum wage set by law above PPP\$10 per day; Collective bargaining: Countries without a minimum wage but where wage negotiations are collectively organised. ${ }^{*} p<0.05,{ }^{* *} p<0.01$

Statistical tests of the difference in the probability of food insecurity using countries with collective bargaining as the reference category are also reported in table 1 . Countries with a moderate ( $p=0.016)$ or no/low minimum wage ( $p=0.029)$ had higher moderate or severe food insecurity. However, the null hypothesis could not be rejected when comparing countries with a high minimum wage to countries with collective bargaining $(p=0.053)$. Similar results for low/moderate/severe and severe only measures of food insecurity were observed (see Table 1). In sum, more generous minimum wages and collective bargaining arrangements were associated with less food insecurity.

\section{ARE THE BENEFITS OF WAGE SETTING POLICIES CONCENTRATED AMONG FULL-TIME WORKERS (RQ2)?}

Next we explored whether these policies benefitted full-time workers more than part-time workers and the unemployed. Wage-setting policies appeared beneficial for full-time workers but not the unemployed. The predicted probability of moderate or severe food insecurity among the unemployed remained high, irrespective of wage setting policies (see Figure 1 and Web Appendix 3 for full models). By contrast, among those in full-time employment, the predicted probability of moderate or severe food insecurity was higher in countries without a minimum wage policy (0.31) than it was in countries with collective bargaining $(0.17)$, a difference of 0.14 (Figure 1). Among part-time workers, the predicted probability of food insecurity was 0.32 in countries without a minimum wage policy and 0.22 in countries with collective bargaining, a difference of 0.092 . The risk of food insecurity was lower for both groups when they lived in collective bargaining countries compared to countries with little or no minimum wage, but the reduction was greater for full-time employees $(0.14)$ than part-time employees $(0.092)(0.14-0.092=0.047, p=0.026)$, suggesting the declines in food insecurity are concentrated among full-time employees.

If wage setting policies do not reduce food insecurity among the unemployed then any increase in unemployment due to the wage setting policy would undermine the overall reduction in food insecurity brought about by the policy. Formally modelling this relationship would go 
Figure 1: Predicted probability of moderate/severe food insecurity wage setting regime and by employment status

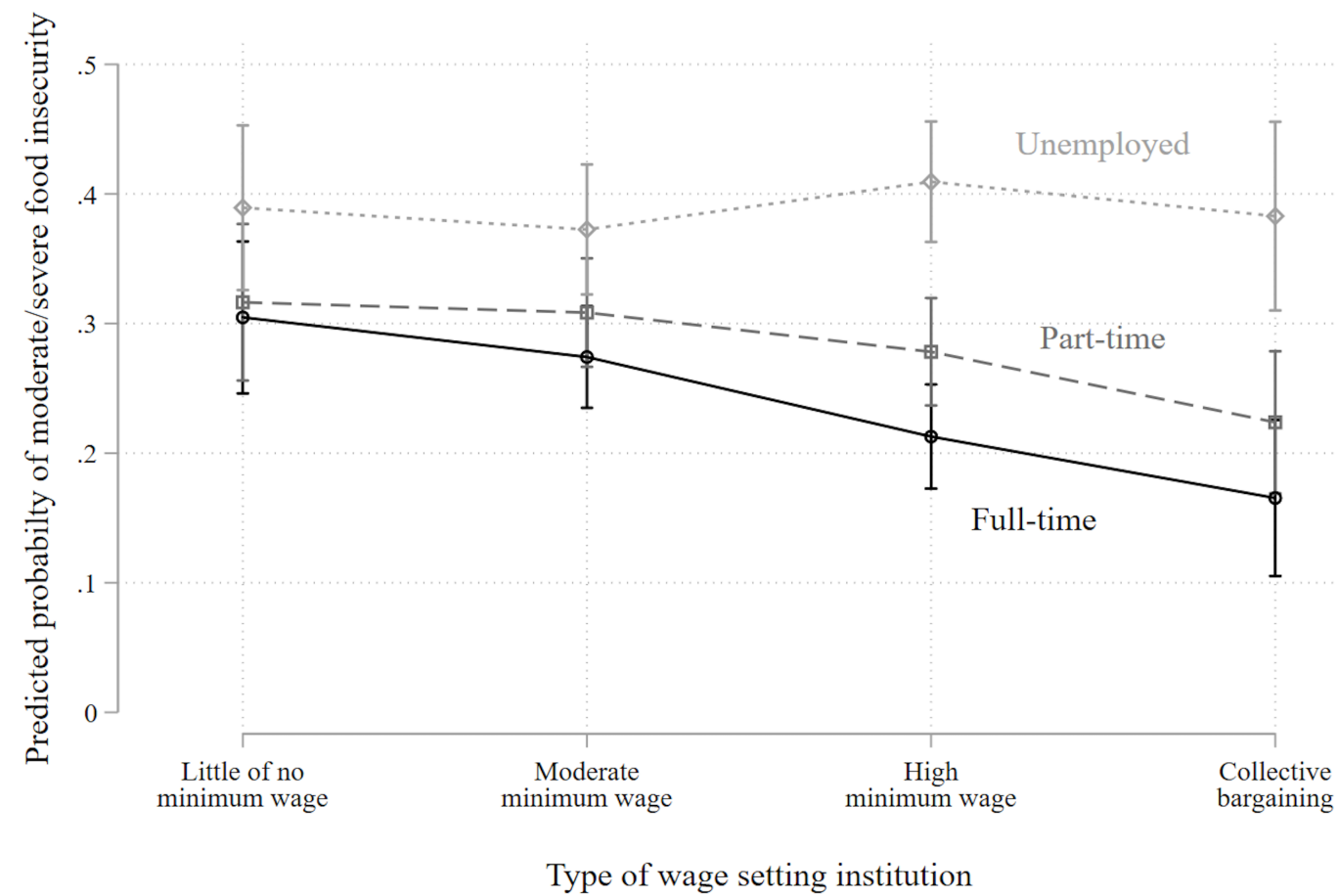

Notes: Results reported in this figure are taken from column 2 of web appendix 3.

beyond the scope of this paper but we have conducted a counterfactual analysis to estimate how large the rises in unemployment would need to be to offset the reductions in food insecurity achieved through increasing the minimum wage (see Web Appendix 4 for more details). The models reported above suggest that moving from a low to a high minimum wage would reduce moderate/severe food insecurity by 4 percentage-points. To offset these gains, the increase in unemployment would need to very large, more than 10 percentage-points.

\section{IS WAGE SETTING POLICY UNDERMINED BY HIGH LEVELS OF LABOUR MAR- KET INFORMALITY (RQ3)?}

Finally, we explored whether the size of the informal economy moderated the impact of wagesetting policy on food insecurity. The direct association between informal labour markets and food insecurity was positive: on average, countries with larger informal economies had higher levels of food insecurity (see Figure 2 and Web Appendix 5). However, as shown in Figure 2, the association between the size of the informal economy and food insecurity appeared to vary according to the kind of wage-setting policies implemented. Among countries with a high or moderate minimum wage, an increase in the proportion of informal workers was clearly associated with higher levels of food insecurity (see Figure 2 and Web Appendix 4). In countries 
Figure 2: Change in predicted probability of moderate or severe food insecurity associated with 1 percentage point increase in the size of the informal labour market by wage setting policy

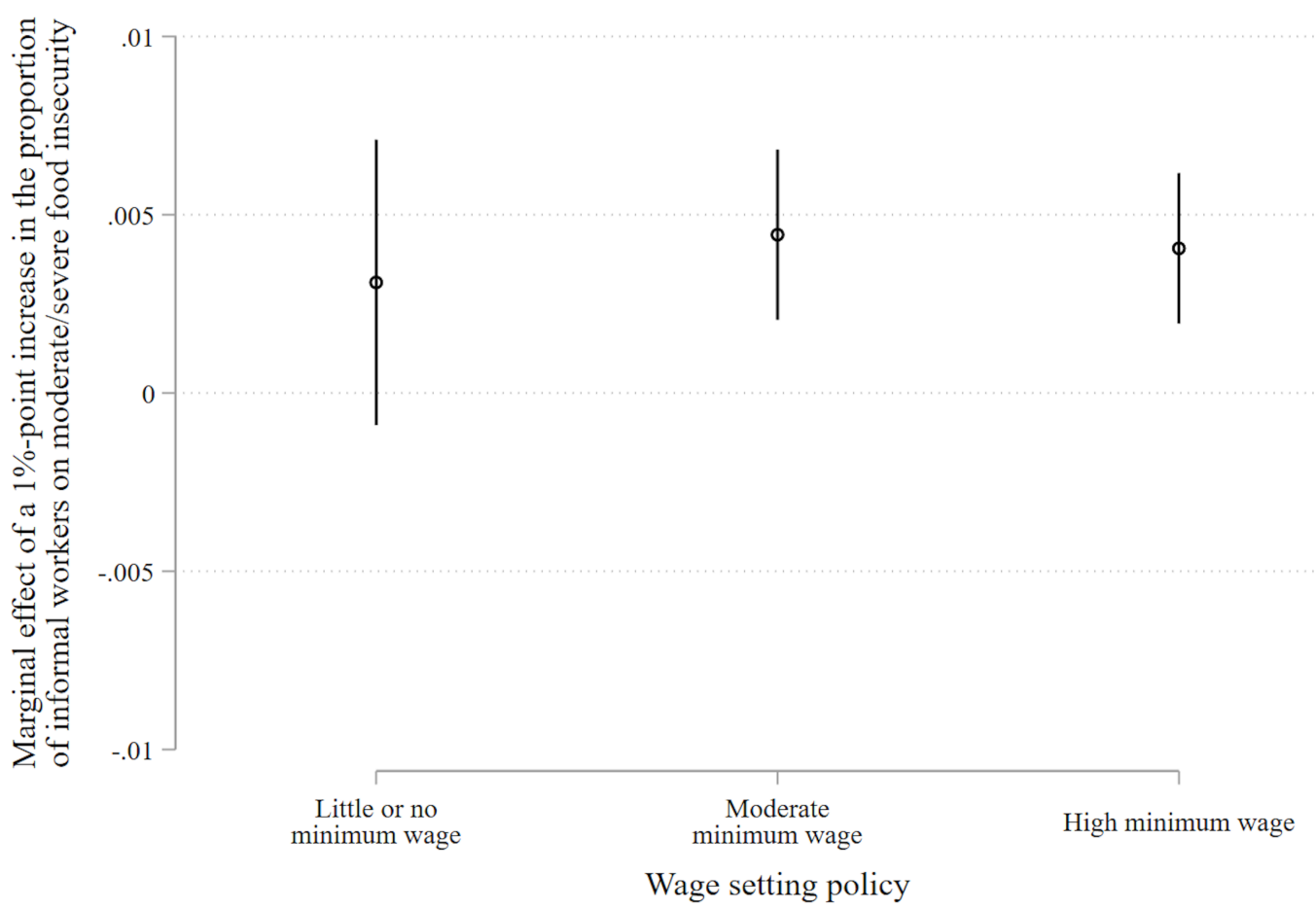

Notes: Results come from the model estimated in table 1 with two changes. First, we have added a measure of the size of the informal labour market and second we added an interaction term between this measure of labour market informality and wage setting policy. Data on labour market informality comes from World Bank.

with little or no minimum wage, the impact of the size of the informal economy on food insecurity was less clear. The association was still positive, but there was far more variation in countries' experience.

\section{SENSITIVITY TESTS}

We conducted a series of sensitivity analyses. First, the findings remained consistent when the models were re-estimated excluding low-income countries, in middle-income countries alone and in high-income countries alone (Web Appendix 6). Second, the results were unchanged after controlling for three other policies that could be associated with wage-setting policies (Web Appendix 7). Third, the results from the matching analysis were consistent with the findings reported above (see Web Appendix 8). 


\section{DISCUSSION}

This paper explored whether wage-setting policies were associated with lower risks of food insecurity. Generous minimum wages and collective bargaining were associated with lower levels of food insecurity. To illustrate our findings, one can consider Costa Rica and Panama. Both are Latin American countries with approximately the same GDP per capita and population size. Costa Rica, however, has a higher minimum wage (over \$10 PPP per day - albeit with some exceptions) while Panama has only a moderate minimum wage (somewhere between $\$ 4.01$ and \$10.00 PPP per day). Panama also has a much higher level of moderate and severe food insecurity ( 30\%) than Costa Rica ( 18\%), suggesting that if Panama increased its minimum wage, then food insecurity may reduce in the population.

These findings add to the growing literature highlighting the health effects of minimum wages and other wage setting policies ${ }^{30}$ but they also reinforce earlier work highlighting how adults in precarious work face greater risks of food insecurity. ${ }^{31}$ Our results not only support these earlier findings, but they also suggest a policy remedy: when countries establish wage setting policies which seek to ensure financial security for low-income households then the risk of food insecurity appear to be lower.

Importantly, however, our results also suggest that wage-setting policies do not benefit everyone to the same degree. The unemployed and those in the informal economy appeared to benefit less from these policies. Part-time workers experienced lower risk of food insecurity but full-time employees experienced even lower risks, most likely because they work more hours. When viewed together, these differences between full-time and part-time workers reinforces other research which has revealed how labour market segmentation can have consequences for poverty and, by implication, health. ${ }^{23,32}$

Labour market segmentation between full-time workers, part-time workers, and the unemployed may be especially important in countries where there are fears that raising the minimum wage will increase unemployment or informality. These risks must be put into perspective, however. Our models suggested any increase in unemployment due to a higher minimum wage would need to be very large to offset the reductions in food insecurity (see Web Appendix 4). Such large rises in unemployment are unlikely because the impact of minimum wages on unemployment are very often negligible, ${ }^{24}$ even in developing countries. ${ }^{33}$ Thus, while pursuing higher minimum wages could create winners and losers in some contexts, it is very likely to lead to a net reduction in food insecurity. Of course, even in these contexts, it would be important to complement policies that increase wages with greater financial protection for the unemployed, which can also lower the risks of food insecurity. ${ }^{11,34}$

There are a number of limitations to our analysis. First, whilst our data covered an unprecedentedly large number of countries, our measure of wage-setting policies did not vary over time, precluding any examination of how changes to wage setting policy affect food insecurity. While the matching analysis partially addresses this issue, in the absence of such changes, it is difficult to draw strong causal conclusions about the association between wage setting policies and food insecurity. Second, the data were not longitudinal data on individuals and so we were 
unable to test what happens to risk of food insecurity when people move into or out of employment under these different policy regimes. Future work will need to examine these issues in more detail.

\section{PUBLIC HEALTH IMPLICATIONS}

Food insecurity is a major health problem that affects educational outcomes, depression, cardiovascular disease, and even mortality. ${ }^{4,5}$ These findings are important because they suggest that food insecurity, and in turn, these health outcomes, may be reduced by the implementation of collective bargaining or high minimum wages. However, the reverse may also be true, namely, that moving away from collective bargaining and higher minimum wages may lead to increasing food insecurity. Indeed, a number of countries have seen major reconfigurations of their wage setting policies in recent decades. There has been a steady erosion of coverage by collective bargaining in Germany, the United Kingdom, and the USA. ${ }^{19}$ At the same time, minimum wages have frequently become less generous in real terms. This analysis suggests public health actors have a role to play in working with other agencies (including government departments) involved in setting labour market protections and wage policies. The retrenchment of wage setting policies not only exacerbates in-work poverty but, as this analysis suggests, may leave families facing insufficient food supplies and, in the worst cases, without enough to eat. ${ }^{35}$

Funding This research was funded in whole, or in part, by the Wellcome Trust 220206/Z/20/Z. For the purpose of Open Access, the author has applied a CC BY public copyright licence to any Author Accepted Manuscript version arising from this submission.

Contributors A. Reeves and R. Loopstra designed the analysis. A. Reeves conducted the analysis and wrote the first draft of the article. R. Loopstra and V. Tarasuk helped interpret the results and helped write the article.

Acknowledgements We thank the Food and Agriculture Organization for sharing the Food Insecurity Experience Scale data with us. 


\section{REFERENCES}

1. Wunderlich G, Norwood J. Panel to Review U.S. Department of Agriculture's Measurement of Food Insecurity and Hunger. Food Insecurity and Hunger in the United States: An Assessment of the Measure, and National Research Council (U.S.). National Academies Press; 2006.

2. Ford ES. Food security and cardiovascular disease risk among adults in the United States: findings from the National Health and Nutrition Examination Survey, 2003-2008. Prev Chronic Dis. 2013;10:E202.

3. Tait CA, L'Abbé MR, Smith PM, Rosella LC. The association between food insecurity and incident type 2 diabetes in Canada: A population-based cohort study. PLoS ONE. 2018;13(5):e0195962.

4. Kirkpatrick SI, McIntyre L, Potestio ML. Child Hunger and Long-term Adverse Consequences for Health. Arch Pediatr Adolesc Med. 2010;164(8):754-762.

5. Faught EL, Williams PL, Willows ND, Asbridge M, Veugelers PJ. The association between food insecurity and academic achievement in Canadian school-aged children. Public Health Nutrition. 2017;20(15):2778-2785.

6. Baten J, Blum M. Growing Tall but Unequal: New Findings and New Background Evidence on Anthropometric Welfare in 156 Countries, 1810-1989. Economic History of Developing Regions. 2012;27(sup1):S66-S85.

7. McDonald CM, Olofin I, Flaxman S, et al. The effect of multiple anthropometric deficits on child mortality: meta-analysis of individual data in 10 prospective studies from developing countries. The American journal of clinical nutrition. 2013;97(4):896-901.

8. Floud R. The Changing Body: Health, Nutrition, and Human Development in the Western World since 1700. Cambridge University Press; 2011.

9. FAO. Prevalence of Undernourishment. Food and Agriculture Organisation; 2019.

10. UN General Assembly. Transforming Our World: The 2030 Agenda for Sustainable Development.; 2015.

11. Loopstra R, Reeves A, Lambie-Mumford H. What Impacts Are Unemployment and the Coronavirus Job Retention Scheme Having on Food Insecurity in the UK?,. Food Foundation; 2020.

12. Smith MD, Rabbitt MP, Coleman- Jensen A. Who are the World's Food Insecure? New Evidence from the Food and Agriculture Organization's Food Insecurity Experience Scale. World Development. 2017;93:402-412.

13. Loopstra R, Reeves A, Tarasuk V. The rise of hunger among low-income households: an 
analysis of the risks of food insecurity between 2004 and 2016 in a population-based study of UK adults. J Epidemiol Community Health. Published online April 9, 2019:jech-2018-211194.

14. Tarasuk V, Fafard St-Germain A-A, Mitchell A. Geographic and socio-demographic predictors of household food insecurity in Canada, 2011-12. BMC Public Health. 2019;19(1):12. doi:10.1186/s12889-018-6344-2 15. FAO. Voices of the Hungry: The Food Insecurity Experience Scale. FAO; 2020.

16. Tarasuk V, Mitchell A, Dachner N. Household Food Insecurity in Canada: 2011. Research to identify policy options to reduce food insecurity Toronto; 2016.

17. Reeves A, Loopstra R, Stuckler D. The growing disconnect between food prices and wages in Europe: cross-national analysis of food deprivation and welfare regimes in twenty-one EU countries, 2004-2012. Public Health Nutrition. 2017;20(8):1414-1422.

18. Loopstra R, Reeves A, McKee M, Stuckler D. Food insecurity and social protection in Europe: Quasi-natural experiment of Europe's great recessions 2004-2012. Preventive Medicine. 2016;89:44-50. doi:10.1016/j.ypmed.2016.05.010

19. Visser J, Hayter S, Gammarano R. Trends in Collective Bargaining Coverage: Stability, Erosion or Decline? International Labour Organization; 2015.

20. Pontusson J, Rueda D, Way CR. Comparative Political Economy of Wage Distribution: The Role of Partisanship and Labour Market Institutions. British Journal of Political Science. 2002;32(2):281-308.

21. Kristal T, Cohen Y, Navot E. Workplace Compensation Practices and the Rise in Benefit Inequality. Am Sociol Rev. 2020;85(2):271-297.

22. Rodgers III WM. The Impact of a $\$ 15$ Minimum Wage on Hunger in America. The Century Foundation; 2016.

23. Emmenegger P, Häusermann S, Palier B, Seeleib-Kaiser M. The Age of Dualization: The Changing Face of Inequality in Deindustrializing Societies. OUP USA; 2012.

24. Dube A, Lester TW, Reich M. Minimum wage effects across state borders: Estimates using contiguous counties. The review of economics and statistics. 2010;92(4):945-964.

25. Card D, Krueger AB. Myth and Measurement: The New Economics of the Minimum Wage - Twentieth-Anniversary Edition. Revised ed. edition. Princeton University Press; 2015.

26. Portes A, Haller W. The Informal Economy. In: Smelser NJ, Swedborg R, eds. The Handbook of Economic Sociology. 2nd ed. Princeton University Press; 2005.

27. Jones AD. Food Insecurity and Mental Health Status: A Global Analysis of 149 Countries. 
American Journal of Preventive Medicine. 2017;53(2):264-273.

28. World Policy Analysis Center. Poverty: Public Use Data Dictionary.; 2014. Accessed February 27, 2020. https://worldpolicycenter.org/maps-data/data-download/world-areas

29. Iacus SM, King G, Porro G. Causal inference without balance checking: Coarsened exact matching. Political analysis. Published online 2011:mpr013.

30. Reeves A, McKee M, Mackenbach J, Whitehead M, Stuckler D. Introduction of a National Minimum Wage Reduced Depressive Symptoms in Low-Wage Workers: A Quasi-Natural Experiment in the UK. Health Econ. 2017;26(5):639-655.

31. Coleman-Jensen AJ. Working for peanuts: Nonstandard work and food insecurity across household structure. Journal of family and economic issues. 2011;32(1):84-97.

32. Barlow P, Reeves A, McKee M, Stuckler D. Employment relations and dismissal regulations: Does employment legislation protect the health of workers? Social Policy \& Administration. 2019;0(0).

33. Bhorat H, Kanbur R, Mayet N. The impact of sectoral minimum wage laws on employment, wages, and hours of work in South Africa. IZA J Labor Develop. 2013;2(1):1.

34. Reeves A, Loopstra R. The Continuing Effects of Welfare Reform on Food Bank use in the UK: The Roll-out of Universal Credit. Journal of Social Policy. Published online 2020:1-21.

35. Riches G, Silvasti T, eds. First World Hunger Revisited: Food Charity or the Right to Food? 2nd edition edition. Palgrave Macmillan; 2014. 


\section{WEB APPENDICES}

Web Appendix 1: List of countries included in the analyses

Web Appendix 2: Descriptive statistics

Web Appendix 3: Predicted probability of food insecurity by the type of wage setting policy and employment status

Web Appendix 4: Calculating the net effect on food insecurity using counterfactual scenarios

Web Appendix 5: Change in predicted probability of severe food insecurity associated with 1 percentage point increase in the size of the informal labour market by wage setting policy

Web Appendix 6: Predicted probability of moderate or severe food insecurity by the type of wage setting policy and by the level of economic development

Web Appendix 7: Predicted probability of food insecurity, moderate or severe food insecurity, and severe food insecurity by the type of wage setting policy, controlling for other policies

Web Appendix 8: Contrasting the predicted probability of insecurity by the type of wage setting policy using countries with Collective Bargaining as the baseline, in a matched sample 
WEB APPENDIX 1: LIST OF COUNTRIES INCLUDED IN THE ANALYSES

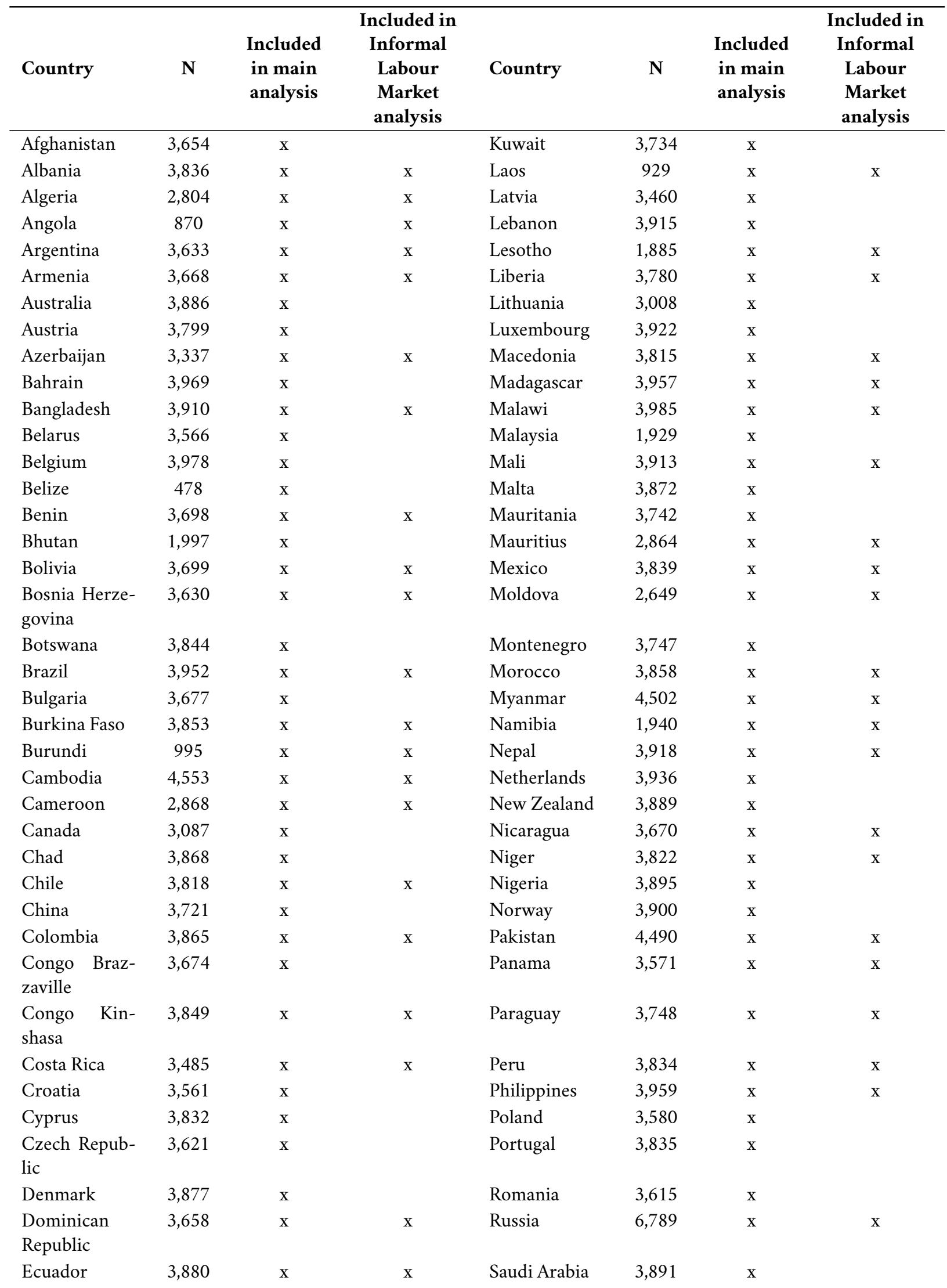




\begin{tabular}{|c|c|c|c|c|c|c|c|}
\hline Egypt & 3,928 & $\mathrm{x}$ & $\mathrm{x}$ & Senegal & 3,922 & $\mathrm{x}$ & $\mathrm{x}$ \\
\hline El Salvador & 3,517 & $\mathrm{x}$ & $\mathrm{x}$ & Serbia & 3,582 & $\mathrm{x}$ & $\mathrm{x}$ \\
\hline Estonia & 3,449 & $\mathrm{x}$ & & Sierra Leone & 3,851 & $\mathrm{x}$ & \\
\hline Ethiopia & 3,935 & $\mathrm{x}$ & & Singapore & 2,833 & $\mathrm{x}$ & \\
\hline Finland & 3,904 & $\mathrm{x}$ & & Slovakia & 3,694 & $\mathrm{x}$ & $\mathrm{x}$ \\
\hline France & 3,891 & $\mathrm{x}$ & & Slovenia & 3,913 & $\mathrm{x}$ & \\
\hline Gabon & 3,827 & $\mathrm{x}$ & & South Africa & 3,923 & $\mathrm{x}$ & $\mathrm{x}$ \\
\hline Gambia & 934 & $\mathrm{x}$ & $\mathrm{x}$ & South Korea & 3,602 & $\mathrm{x}$ & \\
\hline Georgia & 3,682 & $\mathrm{x}$ & & Spain & 1,961 & $\mathrm{x}$ & \\
\hline Germany & 3,760 & $\mathrm{x}$ & & Sri Lanka & 3,044 & $\mathrm{x}$ & $\mathrm{x}$ \\
\hline Ghana & 3,854 & $\mathrm{x}$ & $\mathrm{x}$ & Sudan & 784 & $\mathrm{x}$ & $\mathrm{x}$ \\
\hline Greece & 3,865 & $\mathrm{x}$ & & Sweden & 3,860 & $\mathrm{x}$ & \\
\hline Guatemala & 3,541 & $\mathrm{x}$ & $\mathrm{x}$ & Switzerland & 3,403 & $\mathrm{x}$ & \\
\hline Guinea & 3,853 & $\mathrm{x}$ & & Tanzania & 3,890 & $\mathrm{x}$ & $\mathrm{x}$ \\
\hline Haiti & 1,704 & $\mathrm{x}$ & $\mathrm{x}$ & Thailand & 2,924 & $\mathrm{x}$ & $\mathrm{x}$ \\
\hline Honduras & 3,489 & $\mathrm{x}$ & $\mathrm{x}$ & Togo & 3,777 & $\mathrm{x}$ & $\mathrm{x}$ \\
\hline Hungary & 3,507 & $\mathrm{x}$ & & $\begin{array}{l}\text { Trinidad and } \\
\text { Tobago }\end{array}$ & 455 & $\mathrm{x}$ & \\
\hline Iceland & 1,526 & $\mathrm{x}$ & & Tunisia & 3,848 & $\mathrm{x}$ & $\mathrm{x}$ \\
\hline India & 11,426 & $\mathrm{x}$ & $\mathrm{x}$ & Turkey & 2,841 & $\mathrm{x}$ & $\mathrm{x}$ \\
\hline Indonesia & 3,906 & $\mathrm{x}$ & $\mathrm{x}$ & Uganda & 3,863 & $\mathrm{x}$ & $\mathrm{x}$ \\
\hline Iran & 3,847 & $\mathrm{x}$ & & Ukraine & 3,264 & $\mathrm{x}$ & $\mathrm{x}$ \\
\hline Iraq & 3,867 & $\mathrm{x}$ & & $\begin{array}{l}\text { United Arab } \\
\text { Emirates }\end{array}$ & 6,173 & $\mathrm{x}$ & \\
\hline Ireland & 3,930 & $\mathrm{x}$ & & $\begin{array}{l}\text { United King- } \\
\text { dom }\end{array}$ & 3,912 & $\mathrm{x}$ & \\
\hline Israel & 3,576 & $\mathrm{x}$ & & United States & 2,923 & $\mathrm{x}$ & \\
\hline Italy & 3,925 & $\mathrm{x}$ & & Uruguay & 3,475 & $\mathrm{x}$ & $\mathrm{x}$ \\
\hline Ivory Coast & 3,842 & $\mathrm{x}$ & $\mathrm{x}$ & Uzbekistan & 3,857 & $\mathrm{x}$ & \\
\hline Jamaica & 899 & $\mathrm{x}$ & & Venezuela & 3,861 & $\mathrm{x}$ & $\mathrm{x}$ \\
\hline Japan & 3,636 & $\mathrm{x}$ & & Vietnam & 2,851 & $\mathrm{x}$ & $\mathrm{x}$ \\
\hline Jordan & 3,963 & $\mathrm{x}$ & & Yemen & 3,903 & $\mathrm{x}$ & $\mathrm{x}$ \\
\hline Kazakhstan & 3,502 & $\mathrm{x}$ & & Zambia & 3,883 & $\mathrm{x}$ & $\mathrm{x}$ \\
\hline Kenya & 3,984 & $\mathrm{x}$ & $\mathrm{x}$ & & & & \\
\hline
\end{tabular}


Web ApPEndix 2: DescriPtiVe StATISTICS

\begin{tabular}{|c|c|c|c|c|c|}
\hline Individual-level Variables & Individuals & Mean & Std. Dev & Min & $\operatorname{Max}$ \\
\hline Food insecurity: Any & 492,078 & 0.46 & & 0 & 1 \\
\hline Food Insecurity: Moderate & 492,078 & 0.28 & & 0 & 1 \\
\hline Food Insecurity: Severe & 492,078 & 0.15 & & 0 & 1 \\
\hline Female & 492,078 & 53.23 & & 0 & 1 \\
\hline Age & 492,078 & 41.70 & 17.87 & 15 & 101 \\
\hline Age-squared & 492,078 & 2058.65 & 1687.32 & 225 & 10201 \\
\hline Single/never married & 492,078 & 29.1 & & 0 & 1 \\
\hline Married & 492,078 & 51.58 & & 0 & 1 \\
\hline Divorced/Widowed/Separated & 492,078 & 13.7 & & 0 & 1 \\
\hline Domestic partner & 492,078 & 5.61 & & 0 & 1 \\
\hline Rural & 492,078 & 24.41 & & 0 & 1 \\
\hline Small town & 492,078 & 34.85 & & 0 & 1 \\
\hline Suburb & 492,078 & 10.26 & & 0 & 1 \\
\hline Large city & 492,078 & 30.48 & & 0 & 1 \\
\hline Children under 15 & 492,078 & 52.23 & & 0 & 1 \\
\hline Opportunities to make friends & 492,078 & 78.94 & & 0 & 1 \\
\hline Count on people to help & 492,078 & 80.99 & & 0 & 1 \\
\hline Full-time employed & 492,078 & 27.2 & & 0 & 1 \\
\hline Part-time employed & 492,078 & 15.4 & & 0 & 1 \\
\hline Self-employed & 492,078 & 14.06 & & 0 & 1 \\
\hline Unemployed & 492,078 & 6.48 & & 0 & 1 \\
\hline Economically inactive & 492,078 & 36.87 & & 0 & 1 \\
\hline Country-level Variables & Countries & Mean & Std. Dev & Min & Max \\
\hline $\begin{array}{l}\text { GDP per capita, adjusted for purchasing power and } \\
\text { inflation (log scale) }\end{array}$ & 139 & 8.57 & 1.52 & 5.43 & 11.57 \\
\hline Family policy & 139 & 57.55 & & 0 & 1 \\
\hline Old age pension policy & 130 & 49.23 & & 0 & 1 \\
\hline Maternity and Paternity leave & 139 & 58.27 & & 0 & 1 \\
\hline Size of informal labour force & 72 & 61.61 & 24.99 & 5.9 & 96.2 \\
\hline Population (log scale) & 139 & 16.44 & 1.55 & 12.72 & 21.04 \\
\hline Degree of democracy & 136 & 3.77 & 11.06 & -66 & 10 \\
\hline Little or no minimum wage & 139 & 13.67 & & 0 & 1 \\
\hline Moderate minimum wage & 139 & 41.73 & & 0 & 1 \\
\hline High minimum wage & 139 & 35.97 & & 0 & 1 \\
\hline Collective bargaining & 139 & 8.63 & & 0 & 1 \\
\hline Low income countries & 139 & 17.27 & & 0 & 1 \\
\hline Middle income countries & 139 & 51.08 & & 0 & 1 \\
\hline High income countries & 139 & 31.65 & & 0 & 1 \\
\hline Europe & 139 & 33.09 & & 0 & 1 \\
\hline Middle east and Africa & 139 & 34.53 & & 0 & 1 \\
\hline Asia & 139 & 15.11 & & 0 & 1 \\
\hline Americas & 139 & 17.27 & & 0 & 1 \\
\hline
\end{tabular}


WeB ApPENDIX 3: PREDICTED PROBABILITY OF FOOD INSECURITY BY THE TYPE OF WAGE SETTING POLICY AND EMPLOYMENT STATUS

\begin{tabular}{|c|c|c|c|}
\hline & $\begin{array}{l}\text { Any indication of } \\
\text { food insecurity }\end{array}$ & $\begin{array}{l}\text { Moderate or } \\
\text { severe food } \\
\text { insecurity }\end{array}$ & $\begin{array}{l}\text { Severe food } \\
\text { insecurity }\end{array}$ \\
\hline Wage setting policy & $(1)$ & $(2)$ & (3) \\
\hline \multicolumn{4}{|l|}{ Employed full-time } \\
\hline \multirow[t]{2}{*}{ Little or no wage setting policy } & 0.4949 & 0.3047 & 0.1613 \\
\hline & {$[0.4293,0.5604]$} & {$[0.2461,0.3633]$} & {$[0.1191,0.2034]$} \\
\hline \multirow[t]{2}{*}{ Moderate minimum wage } & 0.4636 & 0.2742 & 0.1406 \\
\hline & {$[0.4198,0.5074]$} & {$[0.2349,0.3134]$} & {$[0.1144,0.1668]$} \\
\hline \multirow[t]{2}{*}{ High minimum wage } & 0.4042 & 0.2128 & 0.0975 \\
\hline & {$[0.3645,0.4438]$} & {$[0.1716,0.2530]$} & {$[0.0670,0.1280]$} \\
\hline \multirow[t]{2}{*}{ Collective bargaining } & 0.3448 & 0.1654 & 0.0644 \\
\hline & {$[0.2703,0.4193]$} & {$[0.1052,0.2255]$} & {$[0.0336,0.0953]$} \\
\hline \multicolumn{4}{|l|}{ Employed part-time } \\
\hline \multirow[t]{2}{*}{ Little or no wage setting policy } & 0.5088 & 0.3164 & 0.1682 \\
\hline & {$[0.4447,0.5729]$} & {$[0.2560,0.3768]$} & {$[0.1221,0.2143]$} \\
\hline \multirow[t]{2}{*}{ Moderate minimum wage } & 0.5149 & 0.3085 & 0.1581 \\
\hline & {$[0.4670,0.5597]$} & {$[0.2666,0.3503]$} & {$[0.1292,0.1871]$} \\
\hline \multirow[t]{2}{*}{ High minimum wage } & 0.4799 & 0.2782 & 0.1353 \\
\hline & {$[0.4412,0.5186]$} & {$[0.2368,0.3196]$} & {$[0.1018,0.1688]$} \\
\hline \multirow[t]{2}{*}{ Collective bargaining } & 0.4323 & 0.2238 & 0.0977 \\
\hline & {$[0.3708,0.49 .38]$} & {$[0.1690,0.2786]$} & {$[0.0619,0.1334]$} \\
\hline \multicolumn{4}{|l|}{ Unemployed } \\
\hline \multirow[t]{2}{*}{ Little or no wage setting policy } & 0.5816 & 0.3893 & 0.2106 \\
\hline & {$[0.5166,0.6467]$} & {$[0.3258,0.4529]$} & {$[0.1625,0.2588]$} \\
\hline \multirow[t]{2}{*}{ Moderate minimum wage } & 0.5816 & 0.3726 & 0.2088 \\
\hline & {$[0.5317,0.6322]$} & {$[0.3224,0.4228]$} & {$[0.1717,0.2460]$} \\
\hline \multirow[t]{2}{*}{ High minimum wage } & 0.6224 & 0.4094 & 0.2252 \\
\hline & {$[0.5836,0.6612]$} & {$[0.3629,0.4558]$} & {$[0.1817,0.2687]$} \\
\hline \multirow[t]{2}{*}{ Collective bargaining } & 0.5834 & 0.3829 & 0.2197 \\
\hline & {$[0.5213,0.6454]$} & {$[0.3101,0.4557]$} & {$[0.1542,0.2852]$} \\
\hline Countries & 139 & 139 & 139 \\
\hline Observations & 492,078 & 492,078 & 492,078 \\
\hline
\end{tabular}


Notes: Confidence intervals reported in parentheses. Estimates come from a multilevel logistic regression model which controls for: sex, age, age-squared, marital status, whether respondents live in an urban or rural area, their employment status, whether there are children in the household under the age of 15, whether respondents are satisfied with their opportunities to make friends, whether respondents have people in their life they can count on, and GDP per capita (adjusted for purchasing power and inflation, measured on a log scale). This model also includes an interaction term between wage setting policy and employment status. The categories of the wage setting policy measure are defined as follows: Little or no wage setting policy: Countries with either (a) no minimum wage or (b) a very low minimum wage ( $<$ PPP\$2 per day); Moderate minimum wage: Countries with a minimum wage set by law between PPP\$2 and PPP\$10 per day; High minimum wage: Countries with a minimum wage set by law above PPP\$10 per day; Collective bargaining: Countries without a minimum wage but where wage negotiations are collectively organised. 


\section{WeB ApPENDIX 4: CALCULATING THE NET EFFECT ON FOOD INSECURITY USING COUNTERFACTUAL SCENARIOS}

One possible issue with our model is that it assumes unemployment remains stable but this may not be true in some instances. Here we use one of our main models to calculate the main effect of moving from a low to high minimum wage setting and then to explore how much according our model - would unemployment need to rise to offset decline in food insecurity generated by the increase in the minimum wage.

Our underlying model is model 2 from web appendix 3 . We start by estimating the level of moderate or severe food insecurity given the average employment structure in our sample (27.29\% are employed full-time, $15.38 \%$ are employed part-time, $13.92 \%$ are self-employed, $6.28 \%$ are unemployed, and $37.13 \%$ are economically inactive).

We start by taking the association between each employment status and moderate or severe food insecurity for countries with little or no minimum wage and we use these parameters (combined with the employment structure noted above) to calculate the proportion of the population that are moderately or severely food insecure, finding that $29.66 \%$ of the population are moderately of severely food insecure (95\% CI: $26.39,32.94)$.

We then use the association between each employment status and moderate or severe food insecurity for countries with a high minimum wage (alongside the same employment structure) to calculate the proportion of moderately or severely food insecure people in a country with a high minimum wage. We find that $25.84 \%$ of the population are moderately or severely food insecure (95\% CI: 23.52, 28.17).

But, this assumes the structure of employment remains unchanged. We then explore what would happen if the unemployment rate increased as a result of these reforms. We start by estimating a 5 percentage-point increase in the unemployment rate (a 2 percentage-point reduction in full-time workers, a 2 percentage-point reduction in part-time workers, and a 1 percentage-point reduction in self-employed workers). We find that the proportion of moderately or severely food insecure people increases to $26.28 \%$ (95\% CI: $24.21,28.35$ ). Note that the confidence intervals from the estimate do not overlap the point estimates from our first model, suggesting that even a 5 percentage-point increase in unemployment would not remove the gains of increasing the minimum wage. Indeed, even if unemployment increased by 10 percentage-points (a 4 percentage-point reduction in full-time workers, a 4 percentagepoint reduction in part-time workers, and a 2 percentage-point reduction in self-employed workers), moderate or severe food insecurity would only rise to $26.96 \%$ (95\% CI: $25.09,28.83$ ), which is still lower than our estimate of the prevalence of food insecurity in a low minimum wage setting (although note that the point estimate of this last estimate does still slightly within the confidence intervals of the low-minimum wage setting estimate). What is clear from this analysis is that, at least in our data, it would require a very large shift in unemployment to offset the gains in food insecurity achieved by increasing the minimum or even implementing collective bargaining. 


\section{WeB APPENDIX 5: CHANGE IN PREDICTED PROBABILITY OF FOOD INSECU- RITY ASSOCIATED WITH 1 PERCENTAGE POINT INCREASE IN THE SIZE OF THE INFORMAL LABOUR MARKET BY WAGE SETTING POLICY}

A. Severe food insecurity

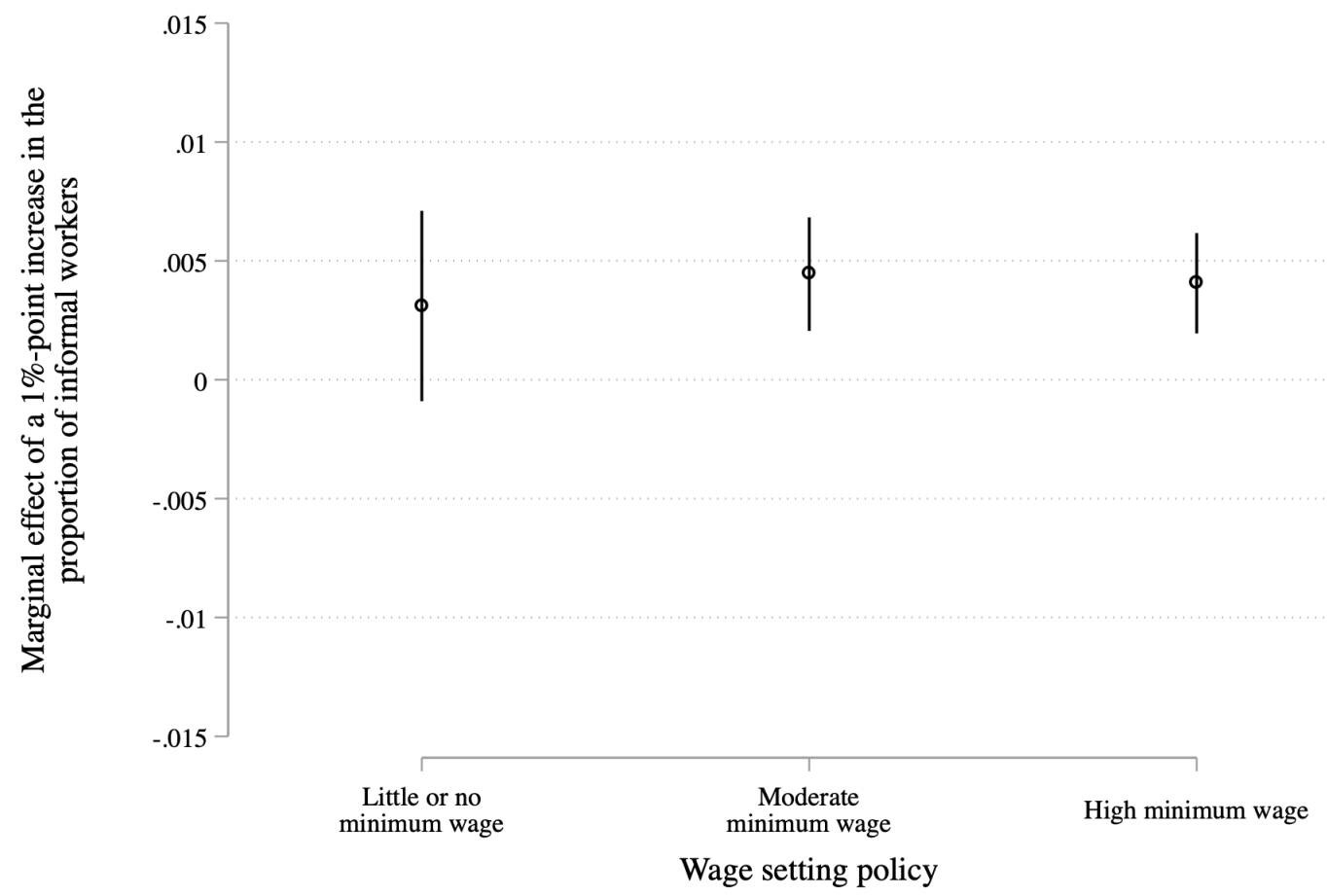

Notes: Results come from the model estimated in table 1 with two changes. First, we have added a measure of the size of the informal labour market and second we added an interaction term between this measure of labour market informality and wage setting policy.

B. Any degree of food insecurity 


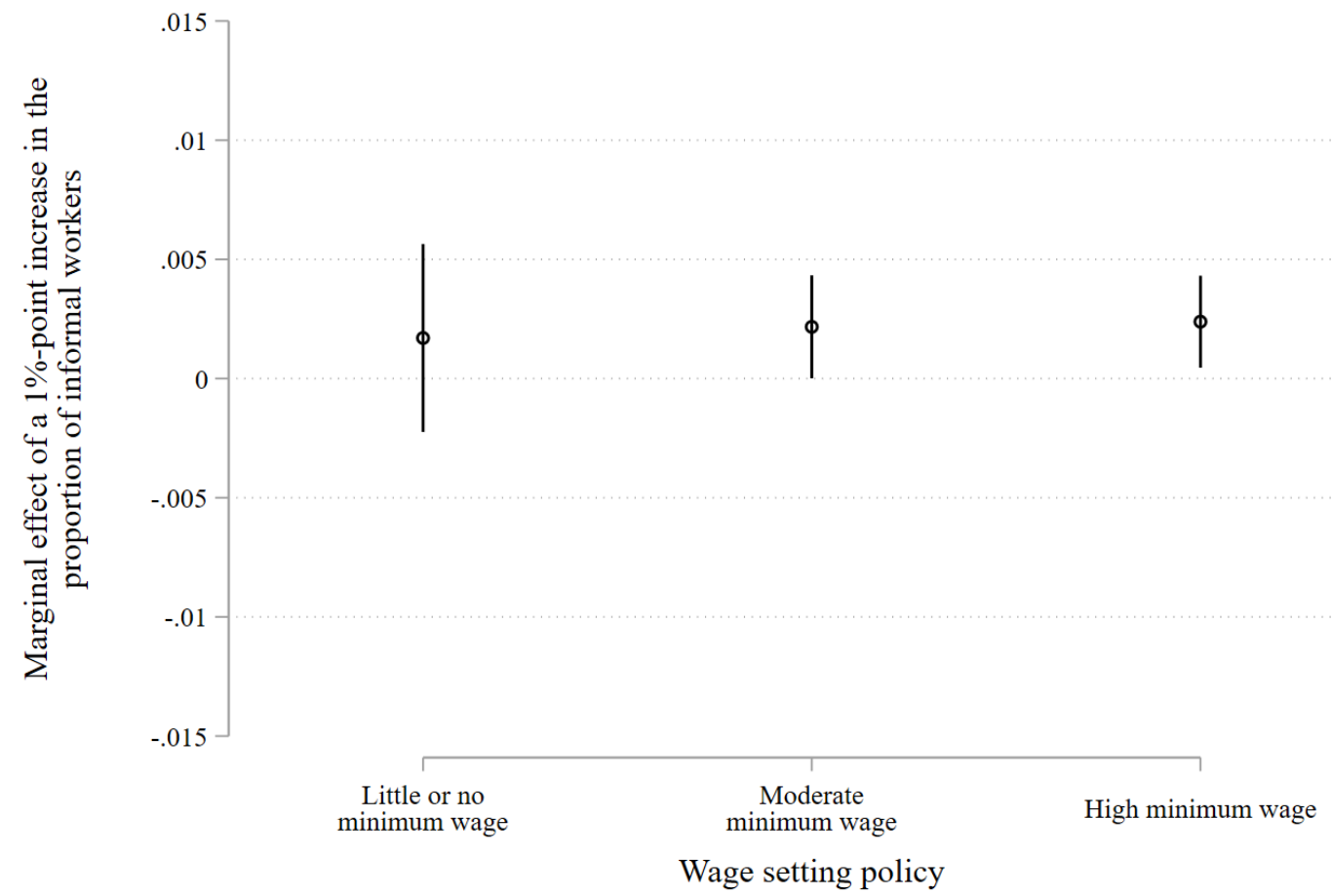

Notes: Results come from the model estimated in table 1 with two changes. First, we have added a measure of the size of the informal labour market and second we added an interaction term between this measure of labour market informality and wage setting policy. 


\begin{tabular}{|c|c|c|c|}
\hline & $\begin{array}{l}\text { Any indication of } \\
\text { food insecurity }\end{array}$ & $\begin{array}{c}\text { Moderate or } \\
\text { severe food } \\
\text { insecurity }\end{array}$ & $\begin{array}{l}\text { Severe food } \\
\text { insecurity }\end{array}$ \\
\hline Wage setting policy & (1) & (2) & (3) \\
\hline Little or no wage setting policy & $\begin{array}{c}0.2419 \\
{[0.1616,0.3223]}\end{array}$ & $\begin{array}{c}0.32 \\
{[0.1820,0.4578]}\end{array}$ & $\begin{array}{c}0.1009 \\
{[0.4614,0.1557]}\end{array}$ \\
\hline Moderate minimum wage & $\begin{array}{c}0.2547 \\
{[0.2069,0.3026]}\end{array}$ & $\begin{array}{c}0.34 \\
{[0.2813,0.3987]}\end{array}$ & $\begin{array}{c}0.0978 \\
{[0.0821,0.1135]}\end{array}$ \\
\hline High minimum wage & $\begin{array}{c}0.1796 \\
{[0.1455,0.2137]}\end{array}$ & $\begin{array}{c}0.2522 \\
{[0.1923,0.3122]}\end{array}$ & $\begin{array}{c}0.0749 \\
{[0.0580,0.0918]}\end{array}$ \\
\hline Collective bargaining & $\begin{array}{c}0.1257 \\
{[0.0874,0.1640]}\end{array}$ & $\begin{array}{c}0.1037 \\
{[0.0945,0.1129]}\end{array}$ & $\begin{array}{c}0.0539 \\
{[0.0393,0.0686]}\end{array}$ \\
\hline Countries & 115 & 71 & 44 \\
\hline Observations & 406,030 & 245,120 & 160,910 \\
\hline
\end{tabular}

Notes: Confidence intervals reported in parentheses. Estimates come from a multilevel logistic regression model which controls for: sex, age, age-squared, marital status, whether respondents live in an urban or rural area, their employment status, whether there are children in the household under the age of 15 , whether respondents are satisfied with their opportunities to make friends, whether respondents have people in their life they can count on, and GDP per capita (adjusted for purchasing power and inflation, measured on a log scale). The categories of the wage setting policy measure are defined as follows: Little or no wage setting policy: Countries with either (a) no minimum wage or (b) a very low minimum wage ( $<$ PPP $\$ 2$ per day); Moderate minimum wage: Countries with a minimum wage set by law between PPP\$2 and PPP\$10 per day; High minimum wage: Countries with a minimum wage set by law above PPP $\$ 10$ per day; Collective bargaining: Countries without a minimum wage but where wage negotiations are collectively organised. 
Web Appendix 7: Predicted PROBABILITY OF FOOd INSECURITY, MODERATE OR SEVERE FOOD INSECURITY, AND SEVERE FOOD INSECURITY BY THE TYPE OF WAGE SETTING POLICY, CONTROLLING FOR OTHER POLICIES

\begin{tabular}{lccc}
\hline & $\begin{array}{c}\text { Any indication of } \\
\text { food insecurity }\end{array}$ & $\begin{array}{c}\text { Moderate or } \\
\text { severe food } \\
\text { insecurity }\end{array}$ & $\begin{array}{c}\text { Severe food } \\
\text { insecurity }\end{array}$ \\
\hline Wage setting policy & $(1)$ & $(2)$ & $(3)$ \\
\hline Little or no wage setting policy & 0.4893 & 0.3195 & 0.1579 \\
& {$[0.4048,0.5737]$} & {$[0.2197,0.4192]$} & {$[0.0924,0.2234]$} \\
Moderate minimum wage & 0.5092 & 0.3482 & 0.1851 \\
& {$[0.4649,0.5534]$} & {$[0.2973,0.3991]$} & {$[0.1491,0.2211]$} \\
High minimum wage & 0.4387 & 0.1953 & 0.0894 \\
Collective bargaining & {$[0.3941,0.4832]$} & {$[0.1594,0.2312]$} & {$[0.0655,0.1133]$} \\
& 0.3806 & 0.124 & 0.0535 \\
Countries & {$[0.3060,0.4552]$} & {$[0.0877,0.1603]$} & {$[0.0340,0.0730]$} \\
Observations & 130 & 130 & 130 \\
\hline
\end{tabular}

Notes: Confidence intervals reported in parentheses. Estimates come from a multilevel logistic regression model which controls for: sex, age, age-squared, marital status, whether respondents live in an urban or rural area, their employment status, whether there are children in the household under the age of 15 , whether respondents are satisfied with their opportunities to make friends, whether respondents have people in their life they can count on, and the level of economic development according to the World Bank. These models also control for pension policy, family policy, and maternity and paternity leave policy. The categories of the wage setting policy measure are defined as follows: Little or no wage setting policy: Countries with either (a) no minimum wage or (b) a very low minimum wage ( $<$ PPP\$2 per day); Moderate minimum wage: Countries with a minimum wage set by law between PPP\$2 and PPP\$10 per day; High minimum wage: Countries with a minimum wage set by law above PPP $\$ 10$ per day; Collective bargaining: Countries without a minimum wage but where wage negotiations are collectively organised. 


\section{WeB APPENDIX 8: CONTRASTING THE PREDICTED PROBABILITY OF FOOD IN- SECURITY BY THE TYPE OF WAGE SETTING POLICY USING COUNTRIES WITH COLLECTIVE BARGAINING AS THE BASELINE, IN A MATCHED SAMPLE}

Countries that have and have not implemented generous wage setting policies may be different in other ways that could be correlated with the risk of food insecurity. We therefore implement a matching procedure as a way of trimming outlier countries from our analysis, thereby focussing on the overlapping parts of the distribution of countries with and without generous wage setting policies. Our treatment variable has been coded as a binary to simplify the matching procedure, where $0=$ countries moderate, little or no minimum wages and $1=$ countries with high minimum wages of collective bargaining. We match on the level of economic development (according to the World Bank), population size, the degree of democracy, and their continent using Coarsened Exact Matching 29. There are 26 possible strata across this combination of variables and we find matched observations in 9 of them. This leaves us with 70 countries and excludes the remaining 69.

\begin{tabular}{lccc}
\hline & $\begin{array}{c}\text { Any } \\
\text { indication of } \\
\text { food } \\
\text { insecurity }\end{array}$ & $\begin{array}{c}\text { Moderate or } \\
\text { severe food } \\
\text { insecurity }\end{array}$ & $\begin{array}{c}\text { Severe food } \\
\text { insecurity }\end{array}$ \\
\hline Wage setting policy & $(1)$ & $(2)$ & $(3)$ \\
\hline Moderate, little, or no wage setting policy & 0.5471 & 0.3296 & 0.1759 \\
& {$[0.4850$,} & {$[0.2698$,} & {$[0.1332$,} \\
High minimum wages or Collective Bargaining & $0.6090]$ & $0.3893]$ & $0.2187]$ \\
& 0.379 & 0.1914 & 0.0866 \\
Difference between the two groups & {$[0.3143$,} & {$[0.1412$,} & {$[0.0554$,} \\
& $0.4438]$ & $0.2416]$ & $0.1178]$ \\
& $0.1680^{* *}$ & $0.1382^{* *}$ & $0.0894^{* *}$ \\
Countries & {$[0.0780$,} & {$[0.0600$,} & {$[0.0369$,} \\
Observations & $0.2578]$ & $0.2164]$ & $0.1418]$ \\
\hline
\end{tabular}

Notes: Standard errors reported in parentheses. Estimates come from a multilevel logistic regression model which controls for: sex, age, age-squared, marital status, whether respondents live in an urban or rural area, their employment status, whether there are children in the household under the age of 15 , whether respondents are satisfied with their opportunities to make friends, whether respondents have people in their life they can count on. The categories of the wage setting policy measure are defined as follows: Little or no wage setting policy: Countries with either (a) no minimum wage or (b) a very low minimum wage (<PPP\$2 per day); Moderate minimum wage: Countries with a minimum wage set by law between PPP\$2 and PPP\$10 per day; High minimum wage: Countries with a minimum wage set by law above PPP\$10 per day; Collective bargaining: Countries without a minimum wage but where wage negotiations are collectively organised. 